\title{
PENGARUH PERPUTARAN MODAL KERJA DAN PERPUTARAN PERSEDIAAN TERHADAP PROFITABILITAS (ROA) PADA PT MAYORA INDAH Tbk TAHUN 2010- 2016
}

\author{
Amthy Suraya ${ }^{1)}$, Lilis Ratnasari ${ }^{2)}$ \\ 1) Dosen universitas pamulang, email : aya081085@gmail.com
}

\section{ARTICLES INFORMATION}

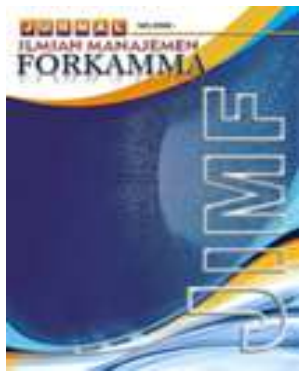

JURNAL ILMIAH MANAJEMEN FORKAMMA

Vol.2, No.2, Maret 2019 Halaman : $96-110$

(c) LPPM \& FORKAMMA

Prodi Magister Manajemen UNVERSITAS PAMULANG

ISSN (online) : 2599-171X

ISSN (print) : :2598-9545

\section{Keyword:}

Perceived Quality, Brand Loyalty, Brand Association, Brand Trust, Customer Loyalty

JEL. classification : C33, G20, G23, N65

\section{Contact Author : \\ PRODI \\ MAGISTER MANAJEMEN \& FORKAMMA UNPAM \\ JL.Surya Kencana No.1 Pamulang \\ Tangerang Selatan - Banten \\ Telp. (021) 7412566, Fax (021) 7412491 Email : \\ jurnalforkamma.unpam@gmail.com}

Tujuan dari penelitian ini adalah untuk mengetahui pengaruh Perputaran Modal Kerja (variabel $X_{1}$ ) dan Perputaran Persediaan (variabel $\mathrm{X}_{2}$ ) terhadap Profitabilitas (variabel $\mathrm{Y}$ ) pada PT. Mayora Indah Tbk. Periode 2010 - 2016. Metode penelitian menggunakan metode pendekatan deskriptif kuantitatif serta analisis data menggunakan analisis regresi linier berganda dan pengujian asumsi klasik yang meliputi : Uji Normalitas, Uji Multikolinieritas, Uji Autokorelasi dan Uji Heteroskedastisitas, Koefisien Determinasi, Regresi Linier Berganda dan Uji Hipotesis yang meliputi: Uji t dan Uji F.

Berdasarkan hasil analisa uji $F$ diperoleh $F_{\text {hitung }}=3,173$ dengan angka signifikasi sebesar $0,149>0,05$ yang artinya $\mathrm{H}_{0}$ diterima dan $\mathrm{H}_{\mathrm{a}}$ ditolak. Analisis regresi linier berganda diperoleh persamaan regresi $Y=21,722-5,397 X_{1}+1,567 X_{2}$. koefisiensi korelasi berganda sebesar 0,783 menunjukkan hubungan yang terjadi adalah sangat kuat, koefisien determinasi $R^{2}$ ditunjuk dengan angka 0,420 yang disimpulkan bahwa perputaran modal kerja dan perputaran persediaan berpengaruh sebesar $42 \%$ terhadap profitabilitas (ROA), sedangkan $58 \%$ dipengaruhi oleh faktor lain yang tidak diteliti.

The purpose of this research was to determine the effect of Working Capital Turnover (variable X1) and Inventory Turnover (variable X2) on Profitability (variable Y) at PT. Mayora Indah Tbk. The 2010-2016 period. The research method used a quantitative descriptive approach and data analysis using multiple linear regression analysis and classical assumption testing which included: Normality Test, Multicollinearity Test, Autocorrelation Test and Heteroscedasticity Test, Correlation Coefficient, Determination Coefficient, Multiple Linear Regression and Test The hypothesis includes: $T$ test and $F$ test.

Based on the results of the $F$ test analysis obtained Fcount $=3.173$ with a significance number of $0.149>0.05$, which means that $\mathrm{HO}$ is accepted and $\mathrm{Ha}$ is rejected. Multiple linear regression analysis obtained a regression equation $Y=$ $21,722-5,397 X 1+1,567$ X2 .. multiple correlation coefficient of 0.783 indicates the relationship that occurs is very strong, $R 2$ coefficient of determination is designated by 0.420 which concluded that working capital turnover and inventory turnover have an effect of $42 \%$ of profitability (ROA), while $58 \%$ is influenced by other factors not examined. 


\section{A. Pendahuluan}

Globalisasi merupakan suatu era dimana kalangan dunia usaha dituntut untuk lebih efektif dalam menjalankan usahanya. Hal ini dikarenakan tidak ada lagi batasan-batasan yang timbul antarnegara. Termasuk dalam bisnis dan persaingan usaha, setiap perusahaan dituntut harus bisa mengelola perusahaannya dengan baik agar dapat bersaing dengan perusahaan-perusahaan lain baik perusahaan domestik maupun perusahaan asing. Salah satu indikator yang dapat digunakan untuk menilai perusahaan terkelola dengan baik adalah bagaimana perusahaan tersebut mengelola modal kerja dan persediaan mereka.

Setiap perusahaan selalu membutuhkan modal kerja untuk membiayai operasinya sehari-hari baik dana yang berasal dari pinjaman maupun dari modal sendiri. Dana tersebut biasanya digunakan untuk dua hal. Pertama, digunakan untuk keperluan investasi artinya dana ini digunakan untuk membeli atau membiaya aktiva tetap dan bersifat jangka panjang yang dapat digunakan secara berulang-ulang, seperti pembelian tanah, bangunan, mesin, kendaraan dan aktiva tetap lainnya. Kedua, dana digunakan untuk pembiayaan jangka pendek, seperti pembelian bahan baku, membayar gaji dan upah serta biaya operasional lainnya. Dimana dana yang telah dikeluarkan diharapkan dapat kembali lagi masuk dalam perusahaan dalam waktu yang pendek melalui hasil penjualan produksinya.

Modal kerja sangat dibutuhkan untuk membiayai aktivitas operasi perusahaan seharihari serta sangat mempengaruhi kontinuitas dari perusahaan itu sendiri. Modal kerja dapat berupa kas dan setara kas, persediaan dan piutang jangka pendek. Jika modal kerja dikelola dengan baik, maka perusahaan tidak akan menemukan banyak kesulitan dan hambatan dalam menjalankan aktivitas operasi perusahaan. Sebaliknya, pengelolaan modal kerja yang tidak tepat dapat menyebabkan aktivitas operasi perusahaan terganggu, dan hal ini merupakan sebab utama kegagalan perusahaan dalam mempertahankan kelangsungan dari perusahaan itu sendiri.

Menurut Kasmir (2011:250), menyatakan bahwa: "Modal kerja diartikan sebagai investasi yang ditanamkan dalam aktiva lancar atau aktiva jangka pendek. Seperti kas, bank, surat-surat berharga, piutang, persediaan, dan aktiva lancar lainnya"

Selain modal kerja ada faktor lain yang mendukung keberhasilan untuk mendapatkan keuntungan laba atau profitabilitas, yaitu faktor perputaran persediaan. Karena dengan mengetahui perputaran persediaan diharapkan dapat memberikan informasi yang akurat kepada pihak yang berkepentingan.

Menurut Sartono (2010 : 443 ) "Persediaan umumnya merupakan salah satu jenis aktiva lancar yang jumlahnya cukup besar dalam suatu perusahaan".

Ukuran yang sering kali digunakan untuk menentukan sukses tidaknya manajemen perusahaan adalah laba (profit) yang diperoleh perusahaan. Berhasil atau tidaknya suatu perusahaan pada umumnya ditandai dengan kemampuan manajemen melihat kemungkinan atau kesempatan dimasa yang akan datang baik jangka pendek maupun jangka panjang dalam meningkatkan profitabilitas perusahaan.

Profitabilitas merupakan kemampuan perusahaan untuk menghasilkan laba dalam hubungannya dengan penjualan, total aktiva maupun modal sendiri sering digunakan untuk mengukur efisiensi penggunaan modal suatu perusahaan dengan membandingkan antara laba dengan modal yang digunakan dalam operasi. Oleh karena itu keuntungan yang besar tidak menjamin atau bukan merupakan ukuran bahwa dalam perusahaan tersebut dapat melangsungkan hidupnya. Profitabilitas merupakan pencerminan dari efisien yang diperhatikan oleh perusahaan adalah tidak hanya bagaimana usaha untuk memperbesar laba, tetapi yang lebih penting adalah usaha mempertinggi profitabilitasnya.

Dalam hal ini perusahaan yang dimaksud adalah PT. Mayora Indah Tbk., merupakan perusahaan yang memproduksi makanan dan minuman olahan, tetapi juga dikenal sebagai market leader yang sukses menghasilkan produk-produk yang menjadi pelopor 
pada kategorinya masing-masing. PT. Mayora Indah Tbk menyajikan laporan keuangan dalam bentuk Neraca dan Laporan Laba Rugi. Laporan keuangan dianalisa setiap tahunnya dan menunjukkan bahwa laba pada PT. Mayora Indah Tbk belum optimal cenderung fluktuatif setiap tahunnya. Modal kerja bersih dan persediaan yang digunakan PT. Mayora Indah setiap tahunnya selalu berubah-ubah dikarenakan modal kerja sangat berpengaruh terhadap perolehan laba perusahaan, maka apabila modal kerja dan persediaan tidak digunakan secara optimal maka perolehan laba yang dihasilkan pun masih fluktuatif. Modal kerja bersih yang besar pun belum bisa dipastikan akan memperoleh laba yang besar juga terkadang mengalami kenaikan atau penurunan secara tiba-tiba dapat dilihat pada laporan laba/rugi perusahaan pada kolom beban operasi hal ini yang mempengaruhi pada peningkatan atau penurunan pemakaian modal kerja. Berikut data keuangan PT. Mayora Indah Tbk. yang menggunakan laporan keuangan dari Bursa Efek Indonesia (BEI) :

\section{Tabel 1.1 \\ Perputaran Modal Kerja, Perputaran Persediaan dan Profitabilitas (ROA) \\ PT. Mayora Indah Tbk Periode 2010 - 2016}

\begin{tabular}{|r|r|r|r|}
\hline Tahun & $\begin{array}{c}\text { Perputaran } \\
\text { Modal } \\
\text { Kerja }\end{array}$ & $\begin{array}{r}\text { Perputaran } \\
\text { Persediaan }\end{array}$ & \multicolumn{1}{|c|}{$\begin{array}{c}\text { Profitabilitas } \\
\text { (ROA) }\end{array}$} \\
\hline 2010 & 4,39 & 11,07 & 14,7 \\
\hline 2011 & 4,20 & 5,83 & 9,49 \\
\hline 2012 & 3,10 & 5,45 & 11,56 \\
\hline 2013 & 3,16 & 6,25 & 13,97 \\
\hline 2014 & 4,17 & 5,92 & 5,14 \\
\hline 2015 & 3,44 & 6,02 & 14,46 \\
\hline 2016 & 3,78 & 6,33 & 14,28 \\
\hline
\end{tabular}

Sumber : data yang diolah dari periode 2010 - 2016

Dari uraian tersebut diatas, maka penulis tertarik melakukan penelitian untuk mengetahui seberapa besar pengaruh perputaran modal kerja dan perputaran persediaan terhadap profitabilitas (ROA). Maka penulis tertarik untuk melakukan pembahasan lebih lanjut yang akan penulis tuangkan dalam skripsi yang berjudul "Pengaruh Perputaran Modal Kerja dan Perputaran Persediaan terhadap Profitabilitas (ROA) Pada PT. Mayora Indah Tbk. tahun 2010 - 2016 ".

\section{B. Perumusan Masalah}

Berdasarkan latar belakang yang telah diungkapkan di atas, maka rumusan masalah dalam penelitian ini adalah :

1. Bagaimana pengaruh perputaran modal kerja terhadap profitabilitas (ROA) pada PT. Mayora Indah Tbk. periode 2010 - 2016 ?

2. Bagaimana pengaruh perputaran persediaan terhadap profitabilitas (ROA) pada PT. Mayora Indah Tbk. periode 2010 - 2016?

3. Bagaimana pengaruh perputaran modal kerja dan perputaran persediaan terhadap profitabilitas (ROA) pada PT. Mayora Indah Tbk. periode 2010 -2016?

\section{Kerangka Berpikir}

Kerangka berfikir penelitian ini dapat digambarkan sebagai berikut: 


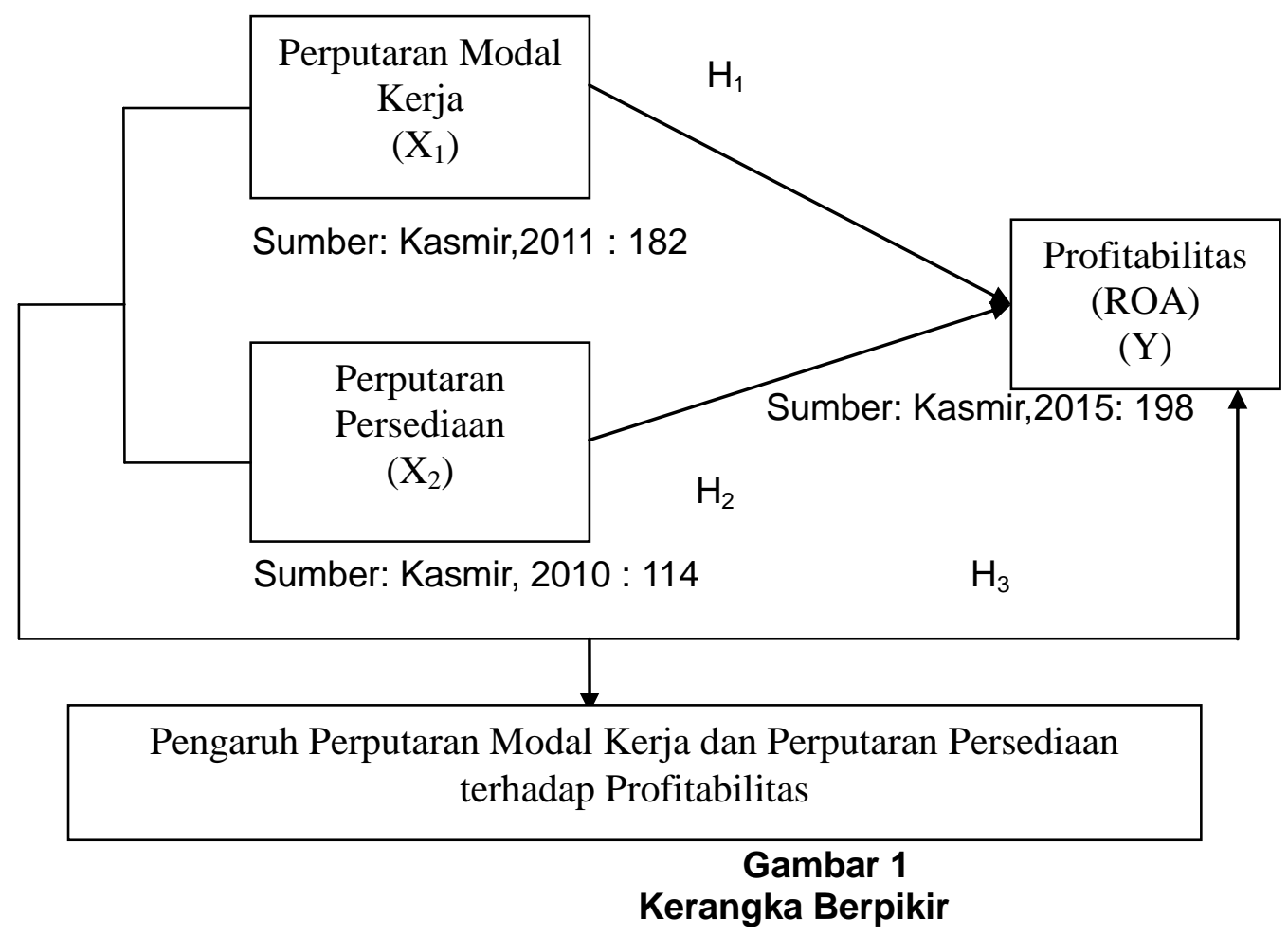

\section{Landasan Teori}

\section{Perputaran Modal Kerja}

Modal kerja merupakan salah satu unsur aktiva yang sangat penting dalam perusahaan. Karena tanpa modal kerja perusahaan tidak dapat memenuhi kebutuhan dana untuk menjalankan aktivitasnya. Masa perputaran modal kerja yakni sejak kas ditanamkan pada elemen-elemen modal kerja hingga menjadi kas lagi, adalah kurang dari satu tahun atau berjangka pendek.

Masa perputaran modal kerja ini menunjukkan tingkat efisiensi penggunaan modal kerja tersebut. semakin cepat masa perputaran modal kerja semakin efisien penggunaan modal kerja, dan tentunya investasi pada modal kerja semakin kecil. Oleh karena itu manajer keuangan dituntut mengelola modal kerja dengan baik sehingga meningkatkan efisiensi modal kerja. Disamping tingkat efisiensi, manajer keuangan juga dituntut untuk memperlihatkan sumber dana untuk memenuhi modal kerja tersebut. Manajer keuangan menghadapi berbagai pilihan sumber dana baik sumber dana jangka pendek maupun berjangka panjang.

Beberapa para ahli mengemukakan pendapat mengenai perputaran modal kerja, yaitu sebagai berikut:

Menurut Kasmir (2011: 182), menyatakan bahwa "perputaran modal kerja atau Working Capital Turnover merupakan salah satu untuk mengukur atau menilai keefektifan modal kerja perusahaan selama periode tertentu". Artinya seberapa banyak modal kerja yang berputar selama satu periode atau dalam satu periode.

Menurut Agus R. Sartono (2010:393) bahwa "perputaran modal kerja berbeda dengan metode keterikatan dana, karena metode ini menentukan kebutuhan modal kerja dengan memperhatikan elemen pembentuk modal kerja itu sendiri seperti kas, piutang dan 
persediaan kemudian untuk mengukur dan menghitung modal kerja digunakan antara lain: perputaran kas, perputaran piutang dan perputaran persediaan".

Perputaran modal kerja menurut Kasmir (2011 : 182) dirumuskan sebagai berikut:

Perputaran Modal Kerja $=\frac{\text { Penjualan }}{\text { Aktiva Lancar-Hutang Lancar }}$

\section{Perputaran Persediaan}

Menurut Sutrisno (2013:89) "Persediaan merupakan bagian utama dari modal kerja, sebab dilihat dari jumlahnya biasanya persediaan inilah unsur modal kerja yang paling besar". Hal ini dapat dipahami karena persediaan merupakan faktor penting dalam menentukan kelancaran operasi perusahaan. Tanpa ada persediaan yang memadai kemungkinan besar perusahaan tidak bisa memperoleh keuntungan yang diinginkan disebabkan proses produksi akan terganggu.

Setiap perusahaan baik yang bergerak dibidang manufaktur, perdagangan, maupun perusahaan jasa mempunyai persediaan. Perbedaan persediaan untuk masing-masing perusahaan tersebut adalah jenis persediaan. Pada perusahaan dagang, sesuai dengan kegiatannya dimana perusahaan ini melakukan kegiatan membeli barang untuk dijual lagi, maka persediaan utama yang dimiliki berupa persediaan barang dagangan, dan persediaan bahan penolong, serta persediaan perlengkapan kantor. Perusahaan jasa mempunyai persediaan biasanya dalam bentuk persediaan bahan pembantu atau persediaan yang habis pakai, termasuk didalamnya persediaan kertas, karbon, stempel, tinta, materai dan persediaan lainnya yang berhubungan dengan jasanya. Sedangkan untuk perusahaan manufaktur mempunyai beberapa macam persediaan utama, diantaranya persediaan bahan baku, persediaan bahan setengah jadi, dan persediaan barang jadi.

Berikut beberapa para ahli mengemukakan pendapat mengenai perputaran persediaan, yaitu sebagai berikut:

Menurut Kasmir (2010 : 114), menerangkan bahwa : "perputaran persediaan merupakan rasio yang digunakan untuk mengukur berapa kali dana yang ditanam dalam persediaan (inventory) yang berputar dalam suatu periode".

Menurut Sofyan Harahap (2011 : 308), perputaran persediaan adalah : "menunjukkan seberapa cepat perputaran persediaan dalam siklus produksi normal, semakin cepat perputaran persediaan maka penjualan berjalan cepat, dan perusahaan dianggap baik dalam usaha memperoleh laba".

Jadi yang dimaksud perputaran persediaan (inventory turnover) adalah rasio yang menunjukkan jumlah persediaan yang perusahaan gunakan untuk mendukung tingkat penjualan tertentu.

Menurut Kasmir (2010 : 114), rumus yang dapat digunakan untuk menghitung perputaran persediaan (inventory turnover) yaitu sebagai berikut:

Perputaran persediaan $=\frac{\text { Harga PokokPenjualan }}{\text { Persediaan }}$

\section{Profitabilitas}

Tujuan akhir yang ingin dicapai suatu perusahaan yang terpenting adalah memperoleh laba atau keuntungan yang maksimal, disamping hal-hal lainnya. Dengan memperoleh laba yang maksimal seperti yang telah ditargetkan, perusahaan dapat berbuat banyak bagi kesejahteraan pemilik, karyawan, serta meningkatkan mutu produk dan melakukan investasi baru. Oleh karena itu, manajemen perusahaan dalam praktiknya dituntut harus mampu untuk memenuhi target yang telah ditetapkan. Artinya besarnya keuntungan haruslah dicapai sesuai dengan yang diharapkan dan bukan berarti asal untung. Untuk mengukur tingkat keuntungan suatu perusahaan, digunakan rasio keuntungan atau rasio profitabilitas yang dikenal juga dengan nama rasio rentabilitas. 
Rasio profitabilitas merupakan rasio untuk menilai kemampuan perusahaan dalam mencari keuntungan. Rasio ini juga memberikan ukuran tingkat efektivitas manajemen suatu perusahaan. Hal ini ditunjukkan oleh laba yang dihasilkan dari penjualan dan pendapatan investasi. Intinya adalah penggunaan rasio ini menunjukkan efisiensi perusahaan.

Menurut Harjito dan Martono (2014:53) "profitabilitas merupakan kemampuan perusahaan untuk memperoleh keuntungan dari penggunaan modalnya".

Dalam praktiknya, jenis-jenis rasio profitabilitas menurut Kasmir (2015: 198) yang dapat digunakan salah satunya adalah:

\section{Hasil Pengembalian Aset (Return on Assets / ROA)}

Return on Assets atau dalam bahasa Indonesia sering disebut dengan tingkat pengembalian aset adalah rasio profitabilitas yang menunjukkan persentase keuntungan (laba bersih) yang diperoleh perusahaan sehubungan dengan keseluruhan sumber daya atau rata-rata jumlah aset. Dengan kata lain, Return on Assets adalah rasio yang mengukur seberapa efisien suatu perusahaan dalam mengelola asetnya untuk menghasilkan laba selama suatu periode. ROA dinyatakan dalam persentase (\%).

Rumus untuk mencari Return on Assets (ROA) dapat digunakan sebagai berikut:

$$
\text { Return on Assets }(R O A)=\frac{\text { Laba Sebelum Pajak }}{\text { Total Aktiva }}
$$

\section{E. Metodologi Penelitian}

Jenis penelitian merupakan penelitian deskriptif kuantitatif karena data penelitian berupa angka-angka yang nantinya akan dianalisis menggunakan statistik. Penelitian ini bertujuan untuk mengetahui pengaruh perputaran modal kerja dan perputaran persediaan terhadap profitabilitas (ROA) pada PT. Mayora Indah Tbk. periode 2010 -2016.

\section{Populasi Dan Sampel}

a) Populasi

Menurut Sugiyono (2015: 80) "populasi adalah wilayah generalisasi yang terdiri dari atas obyek atau subyek yang mempunyai karakteristik tertentu yang diterapkan oleh peneliti untuk dipelajari dan kemudian ditarik kesimpulannya".

Dalam penelitian ini populasinya adalah seluruh laporan keuangan PT. Mayora Indah Tbk.

b) Sampel

Menurut Sugiyono (2015: 81 ) "sampel adalah bagian dari jumlah dan karakteristik yang dimiliki oleh populasi tersebut".

Sampel yang digunakan dalam penelitian ini adalah neraca dan laporan laba rugi PT. Mayora Indah Tbk. tahun 2010 sampai dengan 2016.

\section{Analisis Data}

Dalam penelitian ini akan dianalisis dengan metode-metode diantaranya adalah:

\section{Uji Deskriptif Data}

Analisis deskruptif data dipilih berdasarkan skala pengukurannya. Berdasarkan tujuannya uji deskriptif data yaitu untuk mengetahui gambaran atau penyebaran data sampel atau populasi. Menurut Bambang Suryoatmono (2004:18) menyatakan "statistik deskriptif adalah statistika yang menggunakan data pada suatu kelompok untuk menjelaskan atau menarik kesimpulan mengenai kelompok".

\section{Uji Normalitas}

Menurut Duwi Priyanto (2012:144) "uji normalitas pada model regresi ini digunakan untuk menguji apakah nilai residual yang dhasilkan dari regresi terdistribusi secara normal 
atau tidak". Model regresi yang baik adalah memiliki nilai residual yang terdistribusi secara normal. Pengujian normalitas menggunakan One-sample Kolmogorov-Smirnov Test dengan SPSS 17.0 for windows. Dengan ketentuan, jika nilai Asymp Sig > 0,05 maka data berdistribusi normal.

\section{Uji Multikolinearitas}

Menurut Duwi Priyatno (2012:151) "Multikolinieritas adalah keadaan dimana pada model regresi ditemukan adanya korelasi yang sempurna atau mendekati sempurna antar variabel independen". Pada model regresi yang baik seharusnya tidak terjadi korelasi yang sempurna atau mendekati sempurna diantara variabel bebas (korelasinya 1 atau mendekati 1). Pengujian multikolinearitas dalam penelitian ini menngunakan VIF (Variance Inflation Factor), dengan ketentuan jika nilai tolerance $>0,1$ dan nilai VIF $<10$, maka data tidak maka data tidak mengalami multikolinearitas.

\section{Uji Autokorelasi}

Menurut Duwi Priyatno (2012:172) "autokorelasi adalah keadaan dimana pada model regresi ada korelasi antara residual pada periode $t$ dengan residual pada periode sebelumnya (t-1)". Model regresi yang baik adalah yang tidak terdapat masalah autokorelasi.

\section{Uji Heterokedastisitas}

Menurut Duwi Priyatno (2012:158) "heteroskedastisitas adalah keadaan dimana dalam model regresi terjadi ketidaksamaan varian dari residual pada satu pengamatan yang lain". Model regresi yang baik adalah tidak terjadi heteroskedastisitas.

Untuk mengetahui apakah terjadi heteroskedastisitas atau tidak, dapat dilihat pada gambar Scattreplot, jika pada gambar scatterplot tidak ada pola yang jelas serta titiktitik menyebar diatas dan dibawah angka 0 pada sumbu $Y$, maka tidak terjadi heterokedastisistas.

\section{Analisis Regresi Ganda}

Menurut Sugiyono (2014: 44) "regreasi linier berganda adalah regresi dengan data dua variabel independen $X_{1}$ dan $X_{2}$, dan satu variabel dependen $Y^{\prime \prime}$. variabel $X_{1}$ dan $\mathrm{X}_{2}$ merupakan variabel dependen atau variabel bebas yaitu besaran variabel yang akan mempengaruhi besaran variabel terikat, dalam hal ini adalah Working Capital Turnover dan Inventory Turnover. Variabel $\mathrm{Y}$ merupakan dependen atau variabel terikat yaitu besaran varaiabel akan dipengaruhi besaran variabel bebas, dalam hal ini adalah Profitabilitas perusahaan.

Untuk mengetahui hubungan antara Working Capital Turn Over dan Inventory Turnover terhadap Profitabilitas (ROA) di PT. Mayora Indah Tbk dengan persamaan regresi $\mathbf{Y}=\mathbf{a}+\mathbf{b}_{1} \mathbf{X}_{1}+\mathbf{b}_{2} \mathbf{X}_{2}$

\section{Koefisien Determinasi $\left(\mathbf{R}^{2}\right)$}

"Analisis koefisien determinasi digunakan untuk mengetahui seberapa besar prosentase sumbangan pengaruh variabel indepeden terhadap variabel dependen". (Duwi Priyatno, 2009:56).

\section{Pengujian Hipotesis}

Pengujian hipotesis menurut Sugiyono (2014: 64) "merupakan jawaban sementara terhadap rumusan masalah penelitian, dimana rumusan masalah penelitian telah dinyatakan dalam bentuk kalimat pernyataan". Dikatakan sementara, karena jawaban yang diberikan baru berdasarkan pada teori yang relevan belum didasarkan pada fakta- fakta empiris yang diperoleh melalui pengumpulan data. Jadi hipotesis juga 
dapat dinyatakan sebagai jawaban teoritis terhadap rumusan masalah penelitian, belum jawaban yang empiric.

Pengujian hipotesis dalam penelitian ini dilakukan dalam tiga tahap, yaitu pengujian secara menyeluruh atau simultan (uji F), pengujian individual atau parsial (uji t), dan uji koefisien determinasi $\left(R^{2}\right)$.

a. Pengujian Menyeluruh atau Simultan (uji F)

Untuk menguji signifikan hubungan variabel independen dengan variabel dependen secara simultan, maka digunakan uji F. Menurut Sugiyono (2011:192), rumus yang dapat digunakan untuk dapat melakukan pengujian ini adalah:

$$
F h=\frac{R^{2} / k}{\left(1-R^{2}\right) /(n-k-1)}
$$

b. Pengujian Individual atau Parsial (uji t)

Uji t digunakan untuk menguji secara parsial masing-masing variabel dengan membandingkan $t$ tabel dengan $t$ hitung. Adapun rumus yang digunakan menurut Sugiyono (2011 : 194) dalam menguji hipotesis (uji $t$ ) penelitian ini adalah:

$$
t_{\text {hitung }}=\frac{\sqrt[r p]{n-3}}{\sqrt{1-r_{p}^{2}}}
$$

\section{F. Hasil Analisis Data dan Hasil Penelitian}

Berdasarkan hasil pengolahan data dengan menggunakan bantuan SPSS (statistic product and service solution) versi 20.0 diperoleh perhitungan sebagai berikut:

Tabel 1

Tabel Deskriptif Data Variabel Perputaran Modal Kerja dan Perputaran Persediaam terhadap Profitabilitas (ROA)

Descriptive Statistics

\begin{tabular}{|l|r|r|r|}
\hline & \multicolumn{1}{|c|}{ Mean } & Std. Deviation & \multicolumn{1}{|c|}{ N } \\
\hline ROA & 11.9814 & 3.59404 & 7 \\
Perputaran Modal Kerja & 3.7486 & .52537 & 7 \\
Perputaran Persediaan & 6.6957 & 1.95049 & 7 \\
\hline
\end{tabular}

Sumber: Output SPSS Versi 20.0

Dari tabel 4.7 diatas bahwa jumlah sampel yang digunakan dalam penelitian ini sebanyak 7 yaitu laporan keuangan PT.Mayora Indah Tbk. tahun 2010 - 2016. Kemudian diketahui Profitabilitas (ROA) dengan rata-rata 11,9814 dan standar deviasi nya 3,59404, perputaran modal kerja dengan rata-rata 3,7486 dan standar deviasi nya 0,52537 , dan perputaran persediaan dengan rata-rata 6,6957 dan standar deviasi nya 1,95059.

\section{Pengujian Asumsi Klasik}

a. Uji Normalitas

Uji normalitas dilakukan untuk melihat apakah nilai residual terdistribusi normal atau tidak. Uji normalitas penelitian ini menggunakan One Sample Kolmogrov - Smirov Test dan analisis grafik normal P-P Plot Of Regression Standardized residual. Jika Asymp. Sig (2tailed) diatas tingkat signifikan sebesar 0,05 maka diartikan bahwa variabel-variabel tersebut memiliki distribusi normal dan sebaliknya. Berikut grafik normal P-P Plot Of Regression Standardized residual: 


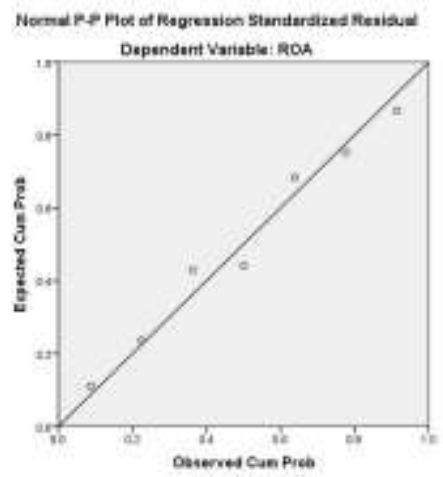

\section{Gambar 2 \\ Normal P-P Plot Of Regression Standardized residual}

Sesuai dengan kriteria prinsip penebaran garis yang dipaparkan di atas, maka dapat disimpulkan bahwa hasil uji normalitas data pada grafik P-P Plot menunjukkan model regresi memenuhi asumsi normalitas dan data menyebar di sekitar garis diagonal dan mengikuti arah garis diagonalnya. Sedangkan hasil pengujian One Sample Kolmogrov - Smirnov Test dapat dilihat pada tabel 4.8 berikut:

Tabel 2

Hasil Uji Sample Kolmogrov - Smirnov

One-Sample Kolmogorov-Smirnov Test

\begin{tabular}{|ll|r|}
\hline & & $\begin{array}{r}\text { Unstandardiz } \\
\text { ed Residual }\end{array}$ \\
\hline Normal Parameters & a,b & Mean \\
& Std. Deviation & $\begin{array}{r}0 \mathrm{E}-7 \\
\text { Most Extreme Differences }\end{array}$ \\
& Absolute & .23467852 \\
& Positive & .148 \\
Kolmogorov-Smirnov Z & Negative & -.148 \\
Asymp. Sig. (2-tailed) & & .393 \\
\hline
\end{tabular}

a. Test distribution is Normal.

b. Calculated from data.

Sumber : Data diolah dengan SPSS 20.

Berdasarkan hasil uji normalitas dengan One - Sample Kolmogrov - Smirnov Test pada tabel 4.8 di atas, diperoleh nilai Test Statistic sebesar 0,393 dan Asymp. Sig. (2tailed) sebesar 0,998 lebih besar dari 0,05 maka dapat disimpulkan data berdistribusi normal.

\section{b. Uji Multikolinieritas}

Uji multikolinieritas digunakan untuk melihat kondisi terdapatnya hubungan linier atau korelasi yang tinggi antara masing-masing variabel independen dalam model regresi. Alat statistik yang sering digunakan untuk menguji gangguan multikolinieritas adalah Variance Inflation Factor (VIF). Identifikasi keberadaan multikolinieritas ini dapat dilihat pada tabel berikut: 
Tabel 3

Tabel Multikolinieritas

\begin{tabular}{|c|c|c|c|c|c|c|c|c|}
\hline \multicolumn{9}{|c|}{ Coefficients $^{\mathrm{a}}$} \\
\hline \multirow[b]{2}{*}{ Model } & & \multicolumn{2}{|c|}{ Unstandardized Coefficients } & \multirow{2}{*}{$\begin{array}{c}\text { Standardized } \\
\text { Coefficients } \\
\text { Beta }\end{array}$} & \multirow[b]{2}{*}{$t$} & \multirow[b]{2}{*}{ Sig. } & \multicolumn{2}{|c|}{ Collinearity Statistics } \\
\hline & & B & Std. Error & & & & Tolerance & VIF \\
\hline 1 & (Constant) & 21.722 & 8.063 & & 2.694 & .054 & & \\
\hline & WCTO & -5.397 & 2.538 & .789 & -2.127 & 101 & .702 & 1.424 \\
\hline & ITO & 1.567 & 684 & .850 & 2.292 & .084 & .702 & 1.424 \\
\hline
\end{tabular}

a. Dependent Variable: ROA

Sumber: Data diolah menggunakan SPSS versi 20

Data hasil uji multikolinieritas di atas di peroleh nilai Tolerance semua variabel $>$ 0,10 dan nilai VIF semua variabel $<10,0$. Karena tidak ada nilai Tolerance $>0,10$ dan nilai VIF $<10,00$. Maka dapat disimpulkan bahwa tidak terjadi gejala multikolinieritas dalam model regresi atau dengan kata lain data memenuhi uji asumsi klasik multikolinieritas.

\section{c. Uji Autokorelasi}

Autokorelasi digunakan untuk menguji apakah dalam sebuah model regresi linier ada korelasi antara kesalahan pengganggu pada periode $t$ dengan kesalahan pada periode t-1 (sebelumnya). Untuk mendeteksi ada tidaknya autokorelasi dapat digunakan uji autokorelasi dengan Run Test, dimana gangguan autokorelasi terjadi jika signifikasi di bawah 0,05. Berikut adalah uji autokorelasi dengan Run Test.

Tabel 4

Uji Autokorelasi dengan Run Test

\begin{tabular}{|l|r|}
\hline \multicolumn{2}{|c|}{ Runs Test } \\
\hline \multicolumn{2}{|c|}{$\begin{array}{r}\text { Unstandardiz } \\
\text { ed Residual }\end{array}$} \\
\hline Test Value $^{\text {a }}$ & -.40412 \\
Cases < Test Value $^{2}$ & 3 \\
Cases > = Test Value & 4 \\
Total Cases & 7 \\
Number of Runs & 3 \\
Z & -.788 \\
Asymp. Sig. (2-tailed) & .431 \\
\hline
\end{tabular}

a. Median

Sumber: Data diolah menggunakan SPSS 20.

Dari hasil uji statistik run test di atas diperoleh nilai signifikansi 0,431>0,05. Karena nilai signifikansi di atas 0,05 maka dapat ditarik kesimpulan bahwa data tidak terjadi problem atau gangguan autokorelasi pada model penelitian atau memenuhi asumsi klasik autokorelasi.

\section{d. Uji Heteroskedastisitas}


Uji heteroskedastisitas yaitu untuk mengetahui ada atau tidaknya ketidaksamaan varian dari residual untuk semua pengamatan pada model regresi. Prasyarat yang harus terpenuhi dalam model regresi adalah tidak adanya masalah heteroskedasitas.

Dalam penelitian ini uji heteroskedasitas dapat dilihat pada grafik scatterplot pada gambar berikut:

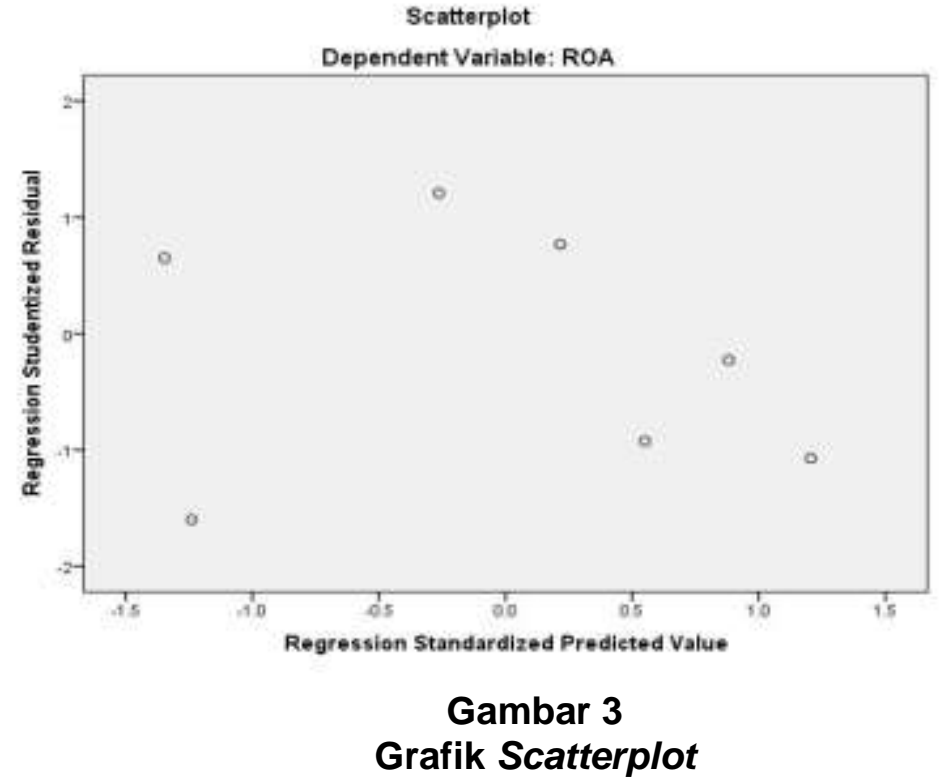

Pada gambar 4.6 di atas dapat dilihat bahwa titik-titik menyebar secara acak dan tidak berkumpul pada satu tempat. Hal ini mengindikasikan bahwa pada data tidak terjadi heteroskedastisitas atau data memenuhi asumsi klasik heteroskedastisitas.

\section{Analisis Regresi Linier Berganda}

Analisis regresi ini digunakan untuk mengetahui seberapa besar pengaruh variabel independen terhadap variabel dependen yaitu perputaran modal kerja dan perputaran persediaan terhadap profitabilitas (ROA) PT. Mayora Indah, Tbk. persamaan regresi linier yang digunakan adalah:

\section{Regresi Linear Berganda}

$$
Y=a+b_{1} X_{1}+b_{2} X_{2}
$$

Adapun perhitungan regresi linier berganda dibantu dengan menggunakan SPSS versi 20 dari data yang telah dianalisis adalah sebagai berikut:

\section{Tabel 4.19}

Hasil analisis Regresi Linier Berganda

\begin{tabular}{|c|c|c|c|c|c|c|}
\hline \multicolumn{7}{|c|}{ Coefficients $^{a}$} \\
\hline \multirow{2}{*}{\multicolumn{2}{|c|}{ Model }} & \multicolumn{2}{|c|}{ Unstandardized Coefficients } & \multirow{2}{*}{$\begin{array}{c}\text { Standardized } \\
\text { Coefficients } \\
\text { Beta }\end{array}$} & \multirow[b]{2}{*}{$t$} & \multirow[b]{2}{*}{ Sig. } \\
\hline & & $\mathrm{B}$ & Std Error & & & \\
\hline \multirow[t]{3}{*}{1} & (Constant) & 21.722 & 8.063 & & 2.694 & .054 \\
\hline & WCTO & -5.397 & 2.538 & -.789 & -2.127 & .101 \\
\hline & ITO & 1.567 & .684 & .850 & 2.292 & .084 \\
\hline
\end{tabular}

Sumber: Data diolah menggunakan SPSS 20.

Dari tabel coefficients di atas maka diperoleh persamaan regresi sebagai berikut:

$$
Y=21,722-5,397 x_{1}+1,567 x_{2}
$$

Persamaan regresi linier berganda di atas mempunyai interpretasi sebagai berikut: 
a) Konstanta (a) sebesar 21,722 menunjukkan bahwa jika perubahan variabel perputaran modal kerja dan perputaran persediaan dianggap konstan atau bernilai 0 (nol), maka nilai profitabilitasnya adalah 21,722.

b) Variabel perputaran modal kerja sebesar $-5,397$ dan bertanda negatif, hal ini berarti bahwa setiap perubahan 1 satuan pada perubahan perpuataran modal kerja akan menurunkan profitabilitas sebesar $-5,397$ dengan arah yang berlawanan. Nilai koefisien yang negatif menunjukkan bahwa perputaran modal kerja berpengaruh negatif terhadap profitabilitas. Semakin tinggi perputaran modal kerja maka semakin menurun profitabilitas.

c) Variabel perputaran persediaan sebesar 1,567. dan bertanda positif, hal ini berarti bahwa setiap perubahan 1 satuan pada perubahan perputaran persediaan akan menaikkan profitabilitas sebesar 1,567 dengan arah yang sama atau searah. Nilai koefisien yang positif menunjukkan bahwa perputaran persediaan berpengaruh positif terhadap profitabilitas. Semakin tinggi perputaran persediaan maka semakin meningkat profitabilitas.

\section{Koefisien Determinasi (Adj. R Square)}

Melalui pengujian bersama-sama dapat diketahui besarnya koefisien determinasi (Adj. $R^{2}$ ) dapat diketahui derajat ketepatan dari analisis regresi linier berganda menunjukkan besarnya variasi sumbangan seluruh variabel bebas terhadap variabel terikatnya. Hasil koefisien determinasi penelitian ini dapat terlihat pada tabel 4.22 Sebagai berikut:

\section{Tabel 5 \\ Hasil Koefisien Determinasi}

Model Summary

\begin{tabular}{|l|r|r|r|r|}
\hline Model & $\mathrm{R}$ & $\mathrm{R}$ Square & $\begin{array}{c}\text { Adjusted } \mathrm{R} \\
\text { Square }\end{array}$ & $\begin{array}{c}\text { Std. Error of } \\
\text { the Estimate }\end{array}$ \\
\hline 1 & $.783^{\mathrm{a}}$ & .613 & .420 & 2.73691 \\
\hline
\end{tabular}

a. Predictors: (Constant), ITO, WCTO

Sumber: Data diolah menggunakan SPSS 20

Berdasarkan tabel model summary besarnya nilai pengaruh variabel bebas ditunjukkan oleh nilai $R^{2}=$ maka $\left.\left(K D=r^{2}\right) \times 100 \%=0,420 \times 100 \%=42 \%\right)$ jadi dapat disimpulkan bahwa perputaran modal kerja dan perputaran persediaan berpengaruh sebesar $42 \%$ terhadap profitabilitas, sedangkan $58 \%$ dipengaruhi oleh variabel lain yang tidak diteliti di dalam penelitian ini.

\section{Pengujian Hipotesis}

a. Uji Signifikansi Parsial (Uji t)

Uji t bertujuan untuk mengetahui pengaruh variabel independen yaitu perputaran modal kerja terhadap profitabilitas pada PT. Mayora Indah Tbk. secara parsial. Hasil uji t penelitian ini dapat dilihat pada tabel 4.13 Sebagai berikut:

\section{Tabel 6}

\section{Hasil Pengujian Uji t}

\begin{tabular}{|c|c|c|c|c|c|c|}
\hline \multicolumn{7}{|c|}{ Coefficients $^{a}$} \\
\hline \multirow{2}{*}{\multicolumn{2}{|c|}{ Model }} & \multicolumn{2}{|c|}{ Unstandardized Coefficients } & \multirow{2}{*}{$\begin{array}{c}\begin{array}{c}\text { Standardized } \\
\text { Coefficients }\end{array} \\
\text { Beta }\end{array}$} & \multirow[b]{2}{*}{$t$} & \multirow[b]{2}{*}{ Sig. } \\
\hline & & B & Std. Error & & & \\
\hline \multirow[t]{2}{*}{1} & (Constant) & 20.312 & 10.937 & & 1.857 & .122 \\
\hline & WCTO & -2.222 & 2.893 & -.325 & -.768 & .477 \\
\hline
\end{tabular}

a. Dependent Variable: ROA 
Sumber: Data diolah menggunakan SPSS 20.

Berdasarkan tabel 4.13 di atas pada variabel perputaran modal kerja di atas diperoleh nilai $t$ hitung sebesar $-0,768$ dengan tingkat signifikansi $5 \%$ dan derajat kebebasan (dk) $n-k$ $=7-2=5$ dengan $t_{\text {tabel }} 2,571$. Dengan melakukan perbandingan yaitu $t_{\text {hitung }}(-0,768)<t$ tabel $(2,571)$ sehingga jatuh pada daerah penerimaan $\mathrm{H}_{0}\left(\mathrm{H}_{0}\right.$ diterima, $\mathrm{H}_{a}$ ditolak). Serta dilihat pada tabel 4 di atas dapat dilihat pula besar angka signifikansi yaitu 0,477 yang berarti angka ini lebih besar dari tingkat signifikansi $(0,477>0,05)$, maka dapat ditarik kesimpulan bahwa perubahan perputaran modal kerja secara parsial berpengaruh terhadap perubahan profitabilitas (ROA) tetapi tidak signifikan.

Tabel 7

Hasil Pengujian Uji t

\begin{tabular}{|c|c|c|c|c|c|c|}
\hline \multicolumn{7}{|c|}{ Coefficients $^{a}$} \\
\hline \multirow{2}{*}{\multicolumn{2}{|c|}{ Model }} & \multicolumn{2}{|c|}{ Unstandardized Coefficients } & \multirow{2}{*}{$\begin{array}{c}\begin{array}{c}\text { Standardized } \\
\text { Coefficients }\end{array} \\
\text { Beta }\end{array}$} & \multirow[b]{2}{*}{$t$} & \multirow[b]{2}{*}{ Sig. } \\
\hline & & $B$ & Std. Error & & & \\
\hline \multirow[t]{2}{*}{1} & (Constant) & 6.801 & 5.187 & & 1.311 & .247 \\
\hline & ITO & .774 & .748 & .420 & 1.034 & .348 \\
\hline
\end{tabular}

a. Dependent Variable: ROA

Sumber: Data diolah menggunakan SPSS 20.

Berdasarkan tabel 4.17 di atas pada variabel perputaran persediaan diperoleh nilai $t$ hitung sebesar 1,034 dengan tingkat signifikansi $5 \%$ dan derajat kebebasan (dk) $n-k=7-$ $2=5$ dengan $t_{\text {tabel }}$ sebesar 2,571 . Dengan melakukan perbandingan yaitu $t_{\text {hitung }}(1,034)<$ $t$ tabel $(2,571)$ sehingga jatuh pada penerimaan $H_{\circ}\left(H_{\circ}\right.$ diterima, Ha ditolak). Serta dilihat pada tabel di atas dapat dilihat pula besar angka signifikansi yaitu 0,348 yang berarti angka ini lebih besar dari tingkat signifikansi $(0,348>0,05)$, maka dapat ditarik kesimpulan bahwa perubahan perputaran persediaan secara parsial berpengaruh terhadap perubahan profitabilitas (ROA) tetapi tidak signifikan.

\section{b. Uji Signifkansi Simultan (Uji F)}

Uji $\mathrm{F}$ digunakan untuk menguji pengaruh variabel independen yaitu perputaran modal kerja dan perputaran persediaan secara simultan atau bersama-sama terhadap variabel dependen profitabilitas, yaitu dengan membandingkan antara nilai $F_{\text {hitung }}$ dengan $F_{\text {tabel}}$.

Berikut dapat dilihat pada tabel 4.21 perhitungan uji hipotesis yang menggunakan uji signifikansi dengan pengujian menggunakan uji F dihitung melalui SPSS versi 20.

\section{Tabel 8}

Hasil Pengujian Uji F

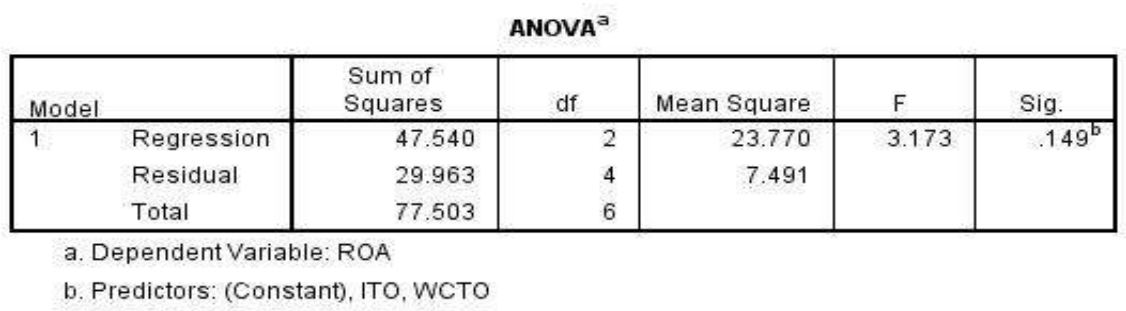

Sumber : Data diolah dengan SPSS 20

Berdasarkan hasil pengujian Analysis of Variance (ANOVA) di atas diperoleh nilai $F$ hitung sebesar 3,173 dengan signifikansi 0 , 149. Sedangkan pada $F$ tabel dengan 
signifikansi $5 \% \mathrm{~d} f 1=\mathrm{k}=2 \mathrm{~d} f 2=\mathrm{n}-\mathrm{k}-1=7-2-1=4$, diperoleh $\mathrm{F}_{\text {tabel }}$ sebesar 6,944. Dengan kondisi ini dimana $F$ hitung lebih kecil dari pada $F$ tabel $(3,173<6,944)$ dan nilai signifikansi lebih besar dari $\alpha=0,05(0,149>0,05)$, maka dapat diambil kesimpulan adalah $\mathrm{H}_{\mathrm{o}}$ diterima dan $\mathrm{H}_{\mathrm{a}}$ ditolak yang berarti secara simultan variabel perputaran modal kerja dan perputaran persediaan berpengaruh terhadap profitabilitas tetapi tidak signifikan.

\section{G. Interpretasi Hasil Pembahasan}

Berdasarkan pembahasan di atas yang menguji pengaruh perputaran modal kerja dan perputaran persediaan terhadap profitabilitas, maka terdapat beberapa hal yang bisa dijelaskan pada penelitian ini, antara lan sebagai berikut:

\section{Pengaruh Perputaran Modal Kerja terhadap Profitabilitas (ROA)}

Dari hasil uji regresi linier sederhana yang diolah menggunakan SPSS versi 20 diperoleh hasil pengujian yang ditemukan adalah nilai signifikansi perputaran modal kerja adalah 0,477 yang berarti angka ini lebih besar dari tingkat $\alpha=5 \%$ atau $0,477>0,05$ dan nilai $t$ hitung sebesar $-0,768$ yang lebih kecil dari nilai $t_{\text {tabel }}$ yaitu sebesar 2,571 atau $(-0$, $768<2,571$ ), sehingga $\mathrm{H}_{0}$ diterima. Dengan demikian ditarik kesimpulan bahwa terdapat pengaruh antara perputaran modal kerja terhadap profitabilitas (ROA) tetapi tidak signifikan pada PT. Mayora Indah, Tbk periode 2010 sampai dengan 2016.

\section{Pengaruh Perputaran Persediaan terhadap Profitabilitas (ROA)}

Dari hasil uji regresi linier sederhana yang diolah menggunakan SPSS versi 20 diperoleh hasil pengujian yang ditemukan adalah nilai signifikansi perputaran persediaan adalah 0,348 yang berarti angka ini lebih besar dari tingkat $\alpha=5 \%$ atau 0,348 $>0,05$ dan nilai $t_{\text {hitung }}$ sebasar 1,034 yang lebih kecil dari nilai $t_{\text {tabel }}$ yaitu sebesar 2,571 atau $(1,034<$ 2,571), sehingga $H_{0}$ diterima. Dengan demikian ditarik kesimpulan bahwa terdapat pengaruh antara perputaran persediaan terhadap profitabilitas (ROA) tetapi tidak signifikan pada PT. Mayora Indah, Tbk periode 2010 sampai dengan 2016.

\section{Pengaruh Perputaran Modal Kerja dan Perputaran Persediaan terhadap Profitabilitas (ROA)}

Dari hasil uji regresi linier berganda yang ditemukan adalah nilai signifikansi perputaran modal kerja adalah 0,101 yang berarti angka ini lebih besar dari tingkat $\alpha=$ $5 \%$ atau $0,101>0,05$. Serta nilai pada signifikansi perputaran persediaan adalah 0,084 yang berarti angka ini lebih besar dari tingkat $\alpha=5 \%$ atau $0,084>0,05$. Kemudian hasil persamaan regresi linier bergandanya adalah $Y=21,722-5,397 \times 1+1,567 \times 2$. Dengan demikian diambil kesimpulan bahwa secara simultan terdapat pengaruh perputaran modal kerja dan perputaran persediaan tetapi tidak signifikan pada PT. Mayora Indah, Tbk periode 2010 sampai dengan 2016.

Selanjutnya berdasarkan hasil uji signifikansi atau hipotesis uji statistik secara simultan, dari hasil penelitian ini menunjukkan bahwa nilai $F_{\text {hitung }}$ adalah sebesar 3,173 dengan taraf signifikansi sebesar 0,149. Dengan demikian nilai $F_{\text {hitung }}(3,173)<F_{\text {tabel }}$ $(6,944)$ dengan taraf signifikansi $(0,149)>(0,05)$, sehingga jauh pada daerah penerimaan $\mathrm{H}_{\mathrm{o}}$. Dengan demikian ditarik kesimpulan bahwa terdapat pengaruh antara perputaran modal kerja dan perputaran persediaan secara simultan (bersama-sama) terhadap profitabilitas (ROA) tetapi tidak signifikan pada PT. Mayora Indah, Tbk periode 2010 sampai dengan 2016.

Kemudian besarnya analisis data yang diperoleh dari nilai $\mathrm{R}^{2}$ (Adjusted $R 2$ ) adalah 0,420 . Hal ini menunjukkan bahwa sebesar $42 \%$ pengaruh perubahan profitabilitas (ROA) dapat dijelaskan oleh variabel perputaran modal kerja dan perputaran persediaan, sedangkan $58 \%$ dipengaruhi oleh variabel lain yang diteliti di dalam penelitian ini. 


\section{H. Kesimpulan}

ISSN (print) : 2598-9545 \& ISSN (online) : 2599-171X

1. Dari hasil analisis perputaran modal kerja mempunyai pengaruh tetapi tidak signifikan terhadap profitabilitas (ROA) PT. Mayora Indah, Tbk. Hasil penelitian secara parsial menunjukkan bahwa $t_{\text {hitung }}<t_{\text {tabel }}$, yaitu $t_{\text {hitung }}$ sebesar $-0,768$ sedangkan $t_{\text {tabel }}$ sebesar 2,571 .

2. Dari hasil analisis perputaran persediaan mempunyai pengaruh tetapi tidak signifikan terhadap profitabilitas (ROA) PT. Mayora Indah, Tbk. Hasil penelitian secara parsial menunjukkan bahwa nilai $t_{\text {hitung }}<t_{\text {tabel }}$, yaitu $t_{\text {hitung }}$ sebesar 1,034 sedangkan $t_{\text {tabel }}$ sebesar 2,571 .

3. Dari hasil koefisien determinasi menunjukkan bahwa sebesar $42 \%$ pengaruh perubahan profitabilitas (ROA) dapat dijelaskan oleh variabel perputaran modal kerja dan perputaran persediaan.

\section{Daftar Pustaka}

Brigham. Houston. 2010. "Dasar-dasar Manajemen Keuangan". Edisi kesebelas, PT. Salemba Empat. Jakarta.

Cut Herlina. 2011. "Dasar-dasar Manajemen Keuangan". Gramedia Pustaka Utama. Jakarta

George. R. Terry dan Leslie W. Rue. 2010. “Dasar-dasar Manajemen”. PT. Bumi Aksara. Jakarta.

Harahap, Sofyan. 2011. "Teori Akuntansi”. Edisi Revisi 2011. Rajawali Pers. Jakarta.

Hasibuan, Malayu. S. P. 2012. Manajemen Sumber Daya Manusia”. Edisi kedua. Cetakan kedelapan belas. BPFE. Yogyakarta.

Harjito. D. A. dan Martono. 2011. "Manajemen Keuangan". Edisi kedua. Ekonisia. Jakarta.

Kampus Fakultas Ekonomi Universitas Islam Indonesia. Yogyakarta.

Irham, Fahmi. 2013."Analisis Laporan Keuangan". Cetakan kedua, Penerbit Alfabeta. Bandung.

Jumingan. 2009. “Analisis Laporan Keuangan”. PT. Bumi Aksara. Jakarta.

Kasmir. 2010. “Analisis Laporan Keuangan”. Raja Grapindo Persada. Jakarta. 2011. “Analisis Laporan Keuangan”. PT. Raja Grapindo Persada. Jakarta.. 2015. "Analisis Laporan Keuangan". Edisi 1-8, Raja Grapindo Persada. Jakarta.

Margaretha, Farah. 2014. "Dasar-dasar Manajemen Keuangan". PT. Dian Rakyat. Jakarta. Munawir, S. 2010. "Analisis Laporan Keuangan". Edisi keempat, PPM. Jakarta.

Priyatno, Duwi. 2012. "Paham Analisis Statistik Data dengan SPSS 20. C.V Andi OFFSET, Yogyakarta.

Sartono, Agus R. 2010. "Manajemen Keuangan Teori dan Aplikasi".Edisi Keempat. BPFE. Yogyakarta.

Sugiyono. 2011. "Metode Penelitian Kuantitatif, Kualitas dan R\&D". cetakan 13, Alfabeta. Bandung.

. 2015."Metode Peneiltian Kuantitatif, Kualitas dan R\&D". Cetakan 21, Alfabeta. Bandung.

Sutrisno. 2013. "Manajemen Keuangan". Edisi kesembilan, PT. Ekonisia. Yogyakarta.

Tampubolon, Manahan. P. 2013. "Manajemen Keuangan (Finance Management)". Cetakan pertama, Mitra Wacana Media. Jakarta.

Veirhzal, Rivai. 2010. “Manajemen Sumber Daya Manusia untuk Perusahaan”. Rajawali Pers. Jakarta. 